Tomasz Kamusella

(D) https://orcid.org/0000-0003-3484-8352

University of St Andrews

\title{
The Jewess Hana, or Antisemitism in the Soviet Bloc*
}

\author{
Jurij Koch: Židowka Hana [The Jewess Hana] \\ (Ser: Kapsne knihi LND, Vol. 35). Illustrated by K.G. Müller. \\ Budyšin [Bautzen, East Germany], \\ Ludowe nakładnistwo Domowina, 1963, 114 pp.
}

\begin{abstract}
Aвstract: The article is devoted to the first novel of the Sorbian writer Jurij Koch entitled Židowka Hana [The Jewess Hana], published in 1963. Curiously, it contains in its title the ethnonym "Jewess," which breached the antisemitic line then adopted across the Soviet bloc. Perhaps, this ideological transgression explains why this novel was not translated into German or the bloc's other languages during the communist period. Sorbian-language novels were (and still are) few and apart, so the East German authorities, for the sake of the official promotion of minority cultures, supported the translation of them into German and other "socialist languages." But not in this case. The important work languished half-forgotten in its Upper Sorbian original and in the 1966 Lower Sorbian translation. Only three decades after the fall of communism and the reunification of Germany, the author prepared and successfully published the German-language version of this novel in 2020.
\end{abstract}

While idly reading books published in too little-known languages, one is sure to stumble across a treasure. After the academic year of 2019-2020, which was blighted by the ongoing pandemic, finally came to an end, I spoiled myself with a shipment of nifty volumes in eastern Germany's Slavic language of Sorbian. Nowadays, after the Germanising ravages in Nazi Germany (1933-1945) and the subsequent subjection of Sorbian language and culture to communist East Germany's ideological needs, ${ }^{1}$ no more than 40,000 to 50,000 people have

* An earlier version of this text was posted on the Silesian and Silesian-language information platform Wachtyrz on 23 June 2020 (https://wachtyrz.eu/the-jewess-hana-and-anti-semi tism-in-the-soviet-bloc/).

${ }^{1}$ M. Nuk: Zatajena njeprawda. Politisce presćéhani w Serbach mjez 1945 a 1989. Budyšin 2004. 
a command of this language. All Sorbian speakers are bilingual in German, yet fewer than half of them use Sorbian in everyday life. ${ }^{2}$ Following the eastward enlargement of the European Union in 2004, their language, quite usefully, allows Sorbs to understand Czech, Polish and Slovak quite easily. This is a good addition to one's $\mathrm{CV}$ when searching for a job in polyglot Europe.

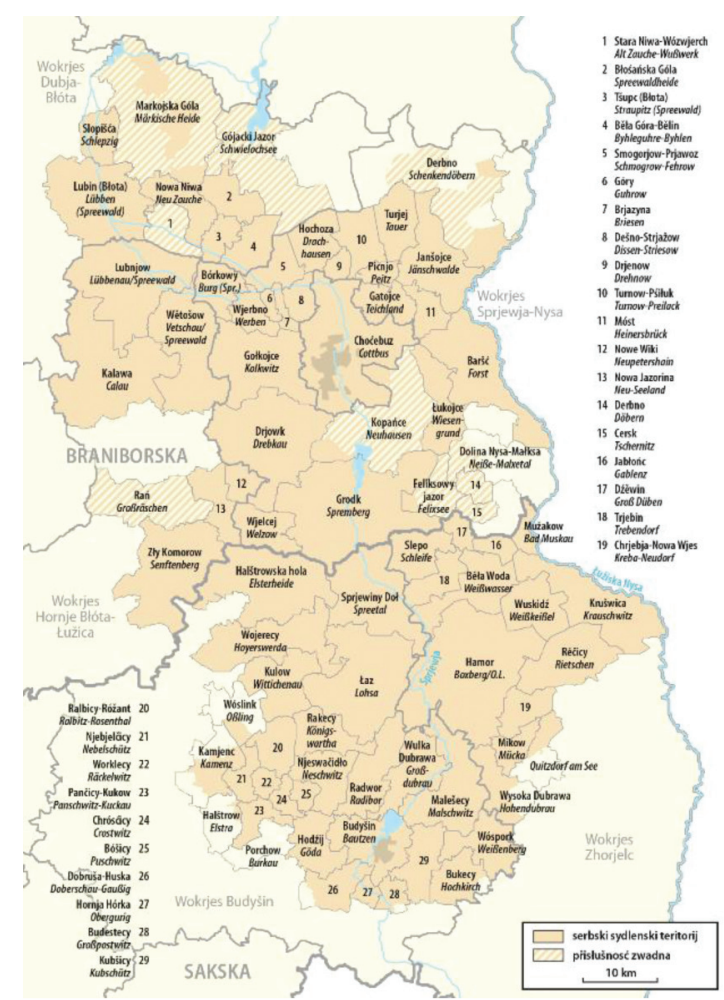

The Sorbian-speaking area today, with the names of places in Sorbian and German Source: Wikimedia Commons, https://commons.wikimedia.org/wiki/File:Sorbisches_Siedlungsgebiet-hsb.png

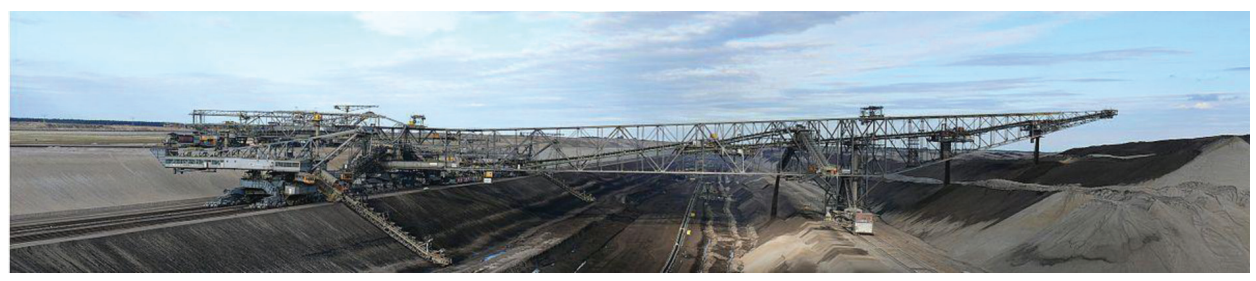

Open-cast lignite mine in Jänschwalde / Janšojce (literally "John’s Forest”) Source: Wikimedia Commons, https://commons.wikimedia.org/wiki/File:F60_in_Betrieb.jpg

2 ferrarij: "Sorbian: An Endangered Language." Taylor Institution Library: A Bodleian Libraries Weblog, 23.11.2015, http://blogs.bodleian.ox.ac.uk/taylorian/2015/11/23/sorbian-an-endange red-language/ [accessed 19.06.2020]. 
Lignite, or brown call, was quarried in the Sorbian historical region of Lusatia (which is today split between Brandenburg and Saxony) for centuries, and since the 1860s mining has taken place on an industrial scale. Open-cast mines were introduced during the communist period, ${ }^{3}$ necessitating the levelling of over 130 Sorbian villages and counting. ${ }^{4}$ The inhabitants were relocated and dispersed in the nearby German-speaking towns and cities. In this manner the overwhelmingly Sorbian-speaking rural communities disappeared overnight, and their former members had no choice but to shift to German for everyday communication. What discrimination could not achieve in the Third Reich was ensured by "progress, industrialisation and socialism" in East Germany. Strangely, following the fall of communism and the reunification of Germany, not much changed. The "economic need" of securing lignite for the power plants that keep producing extremely dirty energy results in the destruction of further Sorbian villages. ${ }^{5}$ The environmental disaster is intimately intertwined with a cultural catastrophe. Despite subsidies for Sorbian schools and cultural organisations, Berlin seems rather unperturbed by the looming disappearance of the last Sorbian-speaking communities. ${ }^{6}$

The aforementioned parcel of books arrived from Budyšyn, or Bautzen in German. Until 1868 the German spelling of this town's name was Budissin, in essence a Latinate rendering of the originally Sorbian name. Among the beautifully crafted volumes, an old 1963 pocket book caught my eye, namely, Židowka Hana, or The Jewess Hana. It relates the poignant story of Hanka Šercec (also spelled in German as Schierz; originally, Annemarie Kreidl, 1918-1943). Her biological mother, Gertrude, was born to the well-to-do owners of an apparel shop in Saxony's capital of Dresden, Bertha ${ }^{7}$ and Carl Kreidl. ${ }^{8}$ At the turn of the

${ }^{3}$ I. Lippert: "'Earth ... without us:' Earthlessness, Autochthoneity and Environmental Risk in Negotiating Mining in Germany." 2020 [Pre-Print]. DOI: 10.31219/osf.io/nvxw8 [accessed 19.06.2020].

${ }^{4}$ H. von der Brelie: "Germany and Poland Have a Dirty Big Secret: An Addiction to Brown Coal." euronews, 30.12.2015, https://www.euronews.com/2015/12/30/germany-and-poland-have-adirty-big-secret-an-addiction-to-brown-coal [accessed 19.06.2020].

5 "Lignite Mining in Lusatia: An Environmental and Cultural Catastrophe." Greens/EFA, 25.02.2015, https://www.greens-efa.eu/en/article/news/lignite-mining-in-lusatia-an-environmen tal-and-cultural-catastrophe/ [accessed 18.06.2020].

${ }^{6}$ Cf. "Sorbian Language Faces Extinction Due to Lack of Teachers." 2010. Nationalia: World news - Stateless Nations and Peoples and Diversity, 16.06.2010, https://www.nationalia.info/ new/9207/sorbian-language-faces-extinction-due-to-lack-of-teachers [accessed 19.06.2020]; "The Battle in Chroscicy to Maintain the use of Sorbian in Education and Administration for the Sorbian Population which Has Traditionally Lived in Upper Lusatia, Saxony." European Parliament, 07.06.2002, https://www.europarl.europa.eu/sides/getDoc.do?type=WQ\&reference=E-20012519\&language $=\mathrm{EN}$ [accessed 19.06.2020].

7 "Berta Dorothea Kreidl (Stransky)." Geni, 2020, https://www.geni.com/people/Berta-Kreidl/6000000015216381993 [accessed 20.06.2020].

8 "Carl / Karl Kreidl." Geni, 2020, https://www.geni.com/people/Carl-Karl-Kreidl/60000000 83839550858 [accessed 20.06.2020]. 
$20^{\text {th }}$ century, this German-speaking family of Jewish background had moved to the Kingdom of Saxony in the German Empire from the nearby Crownland of Bohemia (at present, the western half of the Czech Republic) in Austria-Hungary. When she was a 17-year-old teenager, unmarried Gertrude got pregnant. In this high age of patriarchalism, a child out of wedlock was a huge social problem for any respectable bourgeois family. In order to prevent a scandal, she left Dresden for the village of Horka (Hórki in Sorbian), near Crostwitz (Chrósćicy), located about 50 kilometres northeast of her home city. ${ }^{9}$ In Horka Gertrude befriended Marja (Maria) and Jurij (Georg) Šěrcec (Schierz), sister and brother. They hosted Gertrude in their house and took care of her. In 1918, at the height of the historic social upheavals sweeping across Europe in the wake of the Great War, Gertrude gave birth to Annemarie, and soon afterward entrusted the baby to the peasant sister and brother.

Marja and Jurij brought up Annemarie as their own daughter, speaking Sorbian, and in the Catholic faith. In 1925 they formally adopted her, so Annemarie's family name was officially changed to Schierz. Her adopted parents and the neighbours called the girl Hanka. Meanwhile in Dresden, Gertrude married a befitting spouse, who happened to be a factory owner. After finishing elementary school in 1933, Hanka began to work as a household servant and in the fields. At a time when many young women preferred modern-style "city" clothing, Hanka made a point to always wear the traditional Sorbian folk costume. Furthermore, she knew about her biological mother, and under this influence chose the Jewish name Esther for her Catholic confirmation in $1934 .^{10}$ In the wake of the racist Nuremberg Laws of 1935, people with a parent or grandparent of the Jewish religion were required to sign a Nichtariererklärung (declaration of non-Aryan origin). Hanka signed the document in 1937, but shirked the yellow star, which Germany's Jews were required to wear beginning in 1939. Hanka's adopted father Jurij had already joined the NSDAP in 1933, hoping to protect his daughter. The Gestapo, however, already had Hanka in its crosshairs. ${ }^{11}$

The novel's plot commences at this moment. The doyen of Sorbian literature, Jurij Koch, happened to know the story of Hanka, as he was born in 1936 in the same village of Horka to a stonecutter's family. Židowka Hana was the novel that

9 "Hórka." Wikipedija 2020, https://hsb.wikipedia.org/wiki/Hórka [accessed 18.06.2020].

${ }^{10}$ G. Haase-Hindenberg: "Erzählt es euren Kindern." Jüdische Allgemeine, 20.06.2019, https:// www.juedische-allgemeine.de/unsere-woche/erzaehlt-es-euren-kindern/ [accessed 20.06.2020].

${ }^{11}$ J.-M. Elic: "Ze žiwjenja storhnjena - nic pak z pomjatka Hanka Šřrcec - katolska Serbowka židowskeho pochada.” Katolski Posoł, 14.07.2014, pp. 268-269, www.posol.de/fck/file/ Sercec__KP__2014.pdf [accessed 18.06.2020]; A. Kirschke: "Erinnerungen an eine herzensgute Frau." Sächsische.de, 16.09.2014, https://www.saechsische.de/plus/erinnerung-an-eine-herzensgute-frau-2929486.html [accessed 18.06.2020; R. Ledźbor: “'Nětko mam k njej naraz wěsty zwisk.' W Hórkach kopolak-plesternak za katolsku Serbowku židowskeho pochada Hanu Šěrcec połoženy." Katolski Posoł, 21.09.2014, pp. 276-277, www.posol.de/fck/file/Sercec_KP__2014.pdf [accessed 18.06.2020]. 
first launched Koch's career as a full-fledged Sorbian man of letters. A decade later, in the early 1970s, Koch also began writing in German and self-translating his Sorbian books into this language. At present, aged 84, he is the most prolific Sorbian writer alive. Sadly for Sorbian culture and language, there are no obvious successors in sight.

The novel opens and closes with the haunting image of an oppressive prison. At the book's beginning, it is a psychiatric hospital, where mentally unwell people are apparently killed in line with Nazism's eugenic principle of "lives not worth living." In the coda, however, this place is clearly a concentration camp with Hana in it, wasting away and waiting for the inevitable, the genocidal ideology's "final solution." Within these haunting brackets, life is still as what it used to be in the countryside, governed by the natural cycle of seasons, Catholic holidays and fieldwork. The plot meanders between the village's quarry, tavern and Hana's house. In 1939, a serious and courteous young stonecutter, Bosćij (Sebastian) Lubak, decorously woos Hana in these inauspicious times. Additionally, there is a policeman Beier, who always speaks German and does not seem to understand any of this "damned Sorbian gibberish." In the tavern he drinks and plays cards with stonecutters, making sure they speak German. He also keeps an eye on communists in this unruly bunch of Slavic fellows, who duplicitously pass themselves as Germans. It even seems that Beier killed the hard-of-hearing stonecutter Krawc, who kept talking in Sorbian, not having noticed that the policeman happened to be nearby.

Hanka ordered by policeman Beier to leave the New Year's Eve dancing event (31 December 1940), Židowka Hana (1963), p. 48 Source: my own scan

In 1941, a persistent rumour starts to spread that Hana is a Jewess. On St Nicholas Day (6 December) she dresses up as the saint, who traditionally brings presents to Catholic children across Central Europe, as usual. Beier asks Hana to also hand out presents to his children. Although reluctant at first, the girl convinces herself that it is the Christian thing to do, and that she should not 
suspect people without proof. Three weeks later, Bosćij invites her to the dance on New Year's Eve. Hana would prefer to stay home, but agrees. Shockingly, at the dance Beier orders her to leave the hall in front of all the villagers in order to humiliate Hana even more. Sometime later, the priest asks Hana not to come to church for holy mass. He alludes that it was Beier's strong suggestion, which he has no choice but to follow.

Isolated and excluded from her village community, loyal Bosćij remains Hana's only hope. In mid-1942, an unexpected letter arrives from Switzerland, where Gertrude (Hana's biological mother) and her husband managed to flee from the increasingly antisemitic Third Reich. Bosćij and his stonecutter friends with links to a leftist resistance group make the decision to transport Hana to safety in Switzerland, where she could join her parents. Meanwhile, in early August, Beier orders Hana to come to the tavern where it would finally be ascertained whether she is a Jewess or not, in front of the whole village. Hana fails to appear at the scheduled "trial." Bosćij, together with a couple of stonecutters, whisks Hana away in a truck.

Beier easily sees through the charade and alarms the Gestapo. The truck is quickly discovered and stopped in no time. As a result, Hana is sent to a concentration camp, while her sweetheart and his friends are ordered to the eastern front. Bosćij survived the war, which by then had arrived in the Sorbian homeland, located in the middle of Germany, with the advancing Red Army troops. But no one ever knows what happened to Hana.

In real life, Hana had to stop wearing the folk costume to avoid being accused of concealing her Jewishness under the Sorbian façade. In August 1941, her 70-year-old adopted father Jurij died after a brutal Gestapo interrogation. Beginning in this year, Hana had to regularly report to the Gestapo in Dresden. There is no trace of Hana in documentations after August 1942. There are rumours that she was sighted in the Litzmannstadt (Łódź) Ghetto in occupied Poland. If that is true, Hana died either there or in an extermination camp in 1943. Jews from this ghetto were typically sent to the Kulmhof (Chełmno) or Auschwitz (Oświęcim) death camps. A year earlier, in 1942, her Jewish grandmother, Bertha, aged 69, perished in the Theresienstadt (Terezín) Ghetto in occupied Czechoslovakia. ${ }^{12}$ Hana's adopted mother Marja, with all her immediate family dead, and persecuted for harbouring "the Jewess Hana," died in 1948 at the age of 75 . We know nothing about the fate of Hana's biological mother, Gertrude, and her husband.

There are many stories like this, as six million Jews were murdered by Germans, Austrians and other Nazi supporters across Europe. However, it is surprising that communist East Germany's censors permitted the publication of a wartime novel with the ethnonym Jew/ess prominently featured in its title. In

12 "Berta Dorothea Kreidl (Stransky)..." 
support of the fraternal alliance with the Soviet Union, East Germany's ruling Communist Party (SED, Sozialistische Einheitspartei Deutschlands) encouraged the writing and publication of "anti-fascist literature." ${ }^{13}$ The goal was to prove the country's impeccable "socialist and internationalist" credentials, in stark contrast to the "rotten capitalist West Germany" that harboured convicted Nazi criminals against humanity, such as the industrialist Alfred Krupp. ${ }^{14}$

Undoubtedly, Koch's novel fulfils the party's appeal for anti-fascist literature. Yet this book, without stating it openly, unequivocally alludes to the Holocaust, too. Everyone who lived through the war immediately knew what the writer was talking about. But this was a taboo topic in the increasingly antisemitic Soviet bloc, including in East Germany, which obediently toed the Kremlin's line. ${ }^{15}$ The official line was that all the inhabitants suffered equally during the war, irrespective of creed or language. The work The Black Book of Soviet Jewry authored by the Soviet Jewish writers, Ilya Ehrenburg and Vasily Grossman, was suppressed already in 1948. Joseph Stalin's domestic reaction to the rising Cold War resulted in a campaign against the "rootless cosmopolitans," which was a code phrase for Jews. This purge culminated in the destruction of the Yiddish language and culture, alongside the extermination of leading Soviet Jewish intellectuals and writers from 1950 until Stalin's death in 1953. For example, the first volume of the trilogy The Family Mashber written by the most famous Yiddishlanguage Soviet author, Der Nister, was published in 1939 in Moscow. The second volume came off the press in 1948 in New York, while the third is still hidden in the KGB's archives. ${ }^{16}$ The KGB arrested the writer in 1949, and he died the following year in Vorkuta. ${ }^{17}$

The Soviet bloc countries followed suit, staging show trials of high-ranking communist functionaries, some of Jewish origin, in Hungary, ${ }^{18}$ Czechoslovakia and Romania. ${ }^{19}$ The subsequent flights and expulsions of Jews from these countries were "rounded out" with communist Poland's 1968 ethnic cleansing

${ }^{13}$ Cf. B. Baumann, B. Oberle: Deutsche Literatur in Epochen. Ismaning 1996, pp. 261-262.

${ }^{14}$ Cf. T. Kamusella: "Krupp in Greifswald: On the Perils of Forgetting about the Holocaust." New Eastern Europe, 18.06.2019, https://neweasterneurope.eu/2019/06/18/krupp-in-greifswald-oron-the-perils-of-forgetting-about-the-holocaust/ [accessed 20.06.2020].

${ }^{15}$ Cf. E. Kelly: Composing the Canon in the German Democratic Republic: Narratives of Nineteenth-Century Music. Oxford 2014, p. 77.

${ }^{16}$ G. Kestenbaum: "Hidden Chapters." The New York Jewish Week, 16.07.2019, https://je wishweek.timesofisrael.com/hidden-chapters/ [accessed 21.06.2020].

${ }^{17}$ JTA: "Der Nister Hidden No More: Grave of Influential Yiddish Writer and Soviet Resistance Fighter Discovered at Former Gulag." Jewish Standard, 30.08.2017, https://jewishstandard. timesofisrael.com/der-nister-hidden-no-more/ [accessed 21.06.2020].

${ }^{18}$ Cf. G.H. Hodos: Show Trials: Stalinist Purges in Eastern Europe, 1948-1954. New York 1987.

19 "Pauker, Ana." In: The YIVO Encyclopedia of Jews in Eastern Europe 2020, https://yivoen cyclopedia.org/article.aspx/Pauker_Ana [accessed 21.06.2020]. 
of Jews. ${ }^{20}$ Until the end of communism, history textbooks and museum concentration camps in the Soviet bloc made a point not to reflect on the ethnicity or religion of the Holocaust or war victims. For instance, Jews constituted the overwhelming majority of the over one million people murdered in Auschwitz. ${ }^{21}$ Yet during the communist period, all the victims were simplistically referred to as "Poles." 22

Obviously, books and films about war heroes' and brave resistance fighters' struggle against bloodthirsty Hitlerites were a commonplace across the Soviet bloc. Not only was using the ethnonym "Jew" in titles unacceptable, but communist censorship also made sure that no discernible Jew could be featured as a main protagonist, even if he was a staunch communist, patriot or atheist. Vasily Grossman learned this lesson the hard way when in 1960 the KGB "arrested" his war opus magnum Life and Fate, often compared to Leo Tolstoy's War and Peace. Eventually, a quarter of a century after the writer's death, Mikhail Gorbachev freed the novel and allowed for its publication in 1988, a year before the fall of communism and three years prior to the breakup of the Soviet Union.

This historical context makes the publication of Židowka Hana doubly unusual. The Sorbian-language novel was published in 1963 at the bitter end of the Khrushchev Thaw. A year later, the Soviet leader, Nikita Khrushchev, lost power to a more hardline and less mercurial coterie led by Leonid Brezhnev. In 1966, a Lower Sorbian translation of Koch's novel appeared, titled Žydowka $A n a,{ }^{23}$ just a year prior to the rift between Israel and the Soviet bloc in the wake of the 1967 Six Days' War began. Somehow the subsequent anti-Israeli rhetoric did not prevent the second edition of the Upper Sorbian original published in 1972. Maybe the beginning of détente between the East and West helped. But in the end, East Germany's censors appear to have woken up to a novel with an ideologically unpalatable title, especially since it was relatively popular among the country's "untrustworthy" Sorbian speakers. Tellingly, the book was never republished or let alone translated into German during the communist years.

The end of communism and the reunification of Germany took precedence over such stories. During the 1990 s and at the beginning of the $21^{\text {st }}$ century, former East Germans were busy finding their own place in reunified Germany, where they felt to be second-class citizens. No excess empathy was left to be expanded to the country's ethnically non-German Sorbs or Jews. Apparently, it was Ft Clemens Rehoronly of the Crostwitz/Chrósćicy Parish who inspired some

${ }^{20}$ M. Sieradzka: "Poland Marks 50 Years since 1968 Anti-Semitic Purge." DW, 8.03.2018, https://www.dw.com/en/poland-marks-50-years-since-1968-anti-semitic-purge/a-42877652 [accessed 21.06.2020].

21 "Narodowość i liczba ofiar Auschwitz." 70.auschwitz.org 2020, http://70.auschwitz.org/in dex.php?option=com_content\&view=article\&id=65\&Itemid=176\&lang=pl [accessed 21.06.2020].

${ }^{22}$ Cf. S. Dąbrowa: Ludność cywilna w konfliktach zbrojnych. Warsaw 1973, p. 218.

${ }^{23}$ J. Koch: Žydowka Ana. Trans. W. Bjero. Budyšyn (Bautzen) 1966. 
secondary school students to make the story of Hana their school project at the beginning of the 2010s. This led to more research and, in 2014, the installation of the first-ever Stolperstein (commemoration "stumbling stone" for a Holocaust victim) written in Sorbian. ${ }^{24}$ Fittingly, this stone is dedicated to Hana. ${ }^{25}$ The unprecedented developments must have, at long last, convinced the 84-year-old writer to seize this opportunity. He self-translated the novel into German and titled it Hana. Eine jüdisch-sorbische Erzählung (Hana: A Jewish-Sorbian Story). Leipzig's publishing house which specialises in Jewish culture and history, Hentrich und Hentrich, officially released this long overdue translation in July $2020^{26}$ on Hana's $102^{\text {nd }}$ birthday, 77 years after her death and 57 years after the book's original publication.

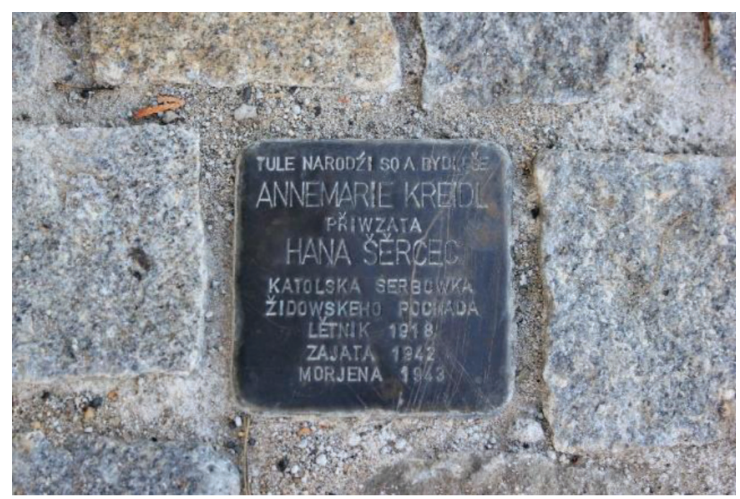

Stolperstein (commemoration "stumbling stone") in Hana's memory

Source: Wikimedia Commons, https://commons.wikimedia.org/wiki/File:Hórki_-_kopolak_za_Hanu__̌̌recec.jpg

Maybe on this memorable occasion a journalist or scholar will convince the great old man of Sorbian literature to reveal how he dealt with the censors - more specifically, to reveal how Jurij Koch and the Sorbian-language publishing house Domowina managed to convince the East German apparatchiks tasked with controlling the Sorbs and their culture that it would be a good idea to permit an explicitly Jewish-themed novel to be published in communist East Germany. Not just once, for that matter, but as many as three times, in spite of the official antisemitic line which was adopted in the Soviet bloc at the beginning of the 1950s. After 1967 this line was even deepened by Moscow's explicit anti-Zionism.

I suspect that the rather small number of potential readers, fully contained to the Sorbian-speaking community, could be an explanation. Although quite

24 "Liste der Stolpersteine in Crostwitz." Wikipedia 2020, https://de.wikipedia.org/wiki/Li ste_der_Stolpersteine_in_Crostwitz [accessed 19.06.2020].

${ }_{25}$ “Eine Märtyrerin in Horka." Sächsische.de, 14.08.2018, https://www.saechsische.de/plus/ eine-maertyrerin-in-horka-3995079.html [accessed 19.06.2020].

${ }^{26}$ J. Koch: Hana. Eine jüdisch-sorbische Erzählung. Leipzig 2020. 
a few Sorbian books were translated into German and also into Czech, Polish or Russian during the communist period for the sake of fostering "international socialist culture," Židowka Hana did not appear in any of these languages. It lingered only in its Upper Sorbian original and the Lower Sorbian translation, inaccessible to non-Sorbian-speaking East Germans. On the other hand, this novel might also have been a tacit warning to "anti-socialist elements," guilty of crimes against humanity committed in the Third Reich, which the ruling SED and the Kremlin knew and remembered. Therefore, they thought they had better closely observe the party's guidance, or else.

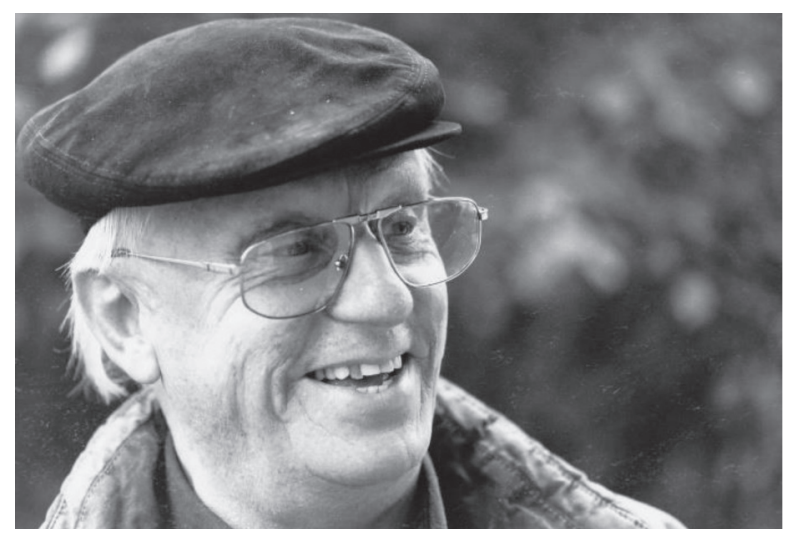

Jurij Koch in 1995

Source: Wikimedia Commons, https://commons.wikimedia.org/wiki/File:Jurij_Koch_(1995).jpg

The intertwined story of Hana and Jurij Koch's novel devoted to this Catholic Sorbian Jewess has been long and unusual, with no end yet in sight. The sad fate of Hana should be better and more widely known, and more research needs to be done, lest we forget. Hence, I hope an English translation of this novel's Sorbian original will follow swiftly, and that the book will be also published in Czech, Polish and other central European languages. Each and every day, speakers of these languages - and of the German language - tread on the ruins and bones of Yiddishland, the world of central Europe's Jews, who are no more. 
Tomasz Kamusella

\author{
Żydówka Hana, albo antysemityzm w bloku sowieckim \\ Jurij Koch: Židowka Hana [The Jewess Hana] (Ser: Kapsne knihi LND, Vol. 35). \\ Illustrated by K.G. Müller. Budyšin [Bautzen, East Germany], \\ Ludowe nakładnistwo Domowina, 1963, 114 pp.
}

\begin{abstract}
Abstrakt: Artykuł ten poświęcony jest pierwszej powieści łużyckiego pisarza Jurija Kocha, o tytule Żydówka Hana, opublikowanej w 1963 roku. Co ciekawe, w tytule książki znalazł się etnonim „Żydówka”, co godziło w antysemicką linię przyjętą wówczas w całym bloku sowieckim. Być może ta ideologiczna transgresja wyjaśnia, dlaczego powieść ta nie została przetłumaczona na język niemiecki, ani na inne języki bloku sowieckiego w okresie komunizmu. Powieści w języku łużyckim były (i nadal są) nieliczne, dlatego władze NRD, ze względu na oficjalną promocję kultur mniejszościowych, wspierały tłumaczenie ich na niemiecki i inne „języki socjalistyczne”. Lecz nie w tym przypadku. To ważne dzieło stało się na wpół zapomniane w górnołużyckim oryginale i przekładzie z 1966 roku na dolnołużycki. Dopiero trzy dekady po upadku komunizmu i zjednoczeniu Niemiec autor przygotował i opublikował w 2020 roku niemieckojęzyczną wersję tej powieści.
\end{abstract}

Tomasz Kamusella - wykładowca (Professor Extraordinarius) historii współczesnej w University of St Andrews w Szkocji. Specjalizuje się w interdyscyplinarnych badaniach nad polityką językową i nacjonalizmem we współczesnej Europie Środkowej. Jego najnowsze publikacje anglojęzyczne obejmują monografie: Ethnic Cleansing During the Cold War: The Forgotten 1989 Expulsion of Turks from Communist Bulgaria (2018), The Un-Polish Poland, 1989 and the Illusion of Regained Historical Continuity (2017) oraz Creating Languages in Central Europe During the Last Millennium (2014). Jest również inicjatorem i współredaktorem następujących prac: The Social and Political History of Southern Africa's Languages (2018), The Palgrave Handbook of Slavic Languages, Identities and Borders (2016) i Creating Nationality in Central Europe, 1880-1950: Modernity, Violence and (Be) Longing in Upper Silesia (2016). W 2019 roku ukazał się jego dwujęzyczny - angielsko-śląski - zbiór opowiadań Limits / Styknie.

Tomasz Kamusella is Reader in Modern History (Professor Extraordinarius) at the University of St Andrews, Scotland, UK. He specialises in the interdisciplinary study of language politics and nationalism in modern central Europe. His recent English-language publications include the monographs Ethnic Cleansing During the Cold War: The Forgotten 1989 Expulsion of Turks from Communist Bulgaria (2018), The Un-Polish Poland, 1989 and the Illusion of Regained Historical Continuity (2017), and Creating Languages in Central Europe During the Last Millennium (2014). He also initiated and coedited the following volumes: The Social and Political History of Southern Africa's Languages (2018), The Palgrave Handbook of Slavic Languages, Identities and Borders (2016), and Creating Nationality in Central Europe, 1880-1950: Modernity, Violence and (Be) Longing in Upper Silesia (2016). Recently, his bilingual, English-Silesian, collection of short stories, Limits / Styknie (2019) appeared. 